\title{
Collective Memory and Cultural-mythological Space
}

\author{
Irina Ponizovkina \\ Department of History and Philosophy \\ Plekhanov Russian University of Economics \\ Moscow, Russia \\ Email: irina-ponizovkin@mail.ru
}

\author{
Elena Agibalova \\ Department of Foreign Languages \\ Plekhanov Russian University of Economics \\ Moscow, Russia \\ E-mail: elenagib@rambler.ru
}

\begin{abstract}
The article considers the important problem of internal interrelation between collective memory and social myth-making in the cultural space. The ambivalent nature of the impact that a myth has on social values associated with the industry of memory is revealed. On the one hand, mythology helps society create its spiritual bonds and preserve valuable historical experience. On the other hand, the myth is actively involved in the management of values through the artificial construction of images of the past. Through the mechanisms of modern myth-making, more and more attempts of spiritual disorientation and reformatting of the cultural code of a particular nation are made.
\end{abstract}

Keywords-mythology; social myth; collective memory; symbol; cultural space; cultural code

\section{INTRODUCTION}

In the modern age, cultural and historic heritage has become especially relevant. S.Huntington wrote about it in his famous geopolitical work The Clash of Civilizations: "Culture is both a divisive and a unifying force... Yet the major differences in political and economic development among civilizations are clearly rooted in their different cultures" [1].Financial capital, scientific and technical potential, labour and natural resources were most often qualified as social development factors by the scholars of the 20 -th century. At the same time, politicians, economists and other analysts often overlooked the fact that with no spiritual resource, all other types of capital may lie without movement, deteriorate or even enrich other countries. In the 21 st century, the resources of spiritual and value orientations of those engaged in the sphere of economic and other relations became an extremely relevant issue.

Spiritual capital does not form on its own and requires diverse activities for its development. Collective memory plays an important role here as it is the core of a cultural code of any nation, people and ethnos in general, which helps them not only acquire "their face" but also occupy their niche in a complicated controversial cultural-historical space.

Today, we can state with certainty that we observe a global memorial boom that has dubious consequences and nature as well as the appearance of a whole "memory industry". With this regard, there is a growing need of additional measures protecting collective memory and its symbols that are able to make cultural space harmonious, familiar and understandable, gain spiritual bonds and valuable historical experience from them.

\section{HISTORICAL BACKGROUND}

There is a cultural phenomenon of diverse research approaches to the nature of cultural-collective memory and the problems of its functioning. Researches of collective memory ("social memory", "cultural memory", "popular memory", "public memory") gained their popularity in the $80-90$-s of the last century as well as postmodern themes in art and philosophy. The French philosopher Maurice Halbwachs who introduced, above all other things, a specific concept of identity into memory studies, is considered the author of collective memory concept. "Halbwach's fundamental contribution into the study of social memory consists in substantiating the connection between a social group and collective memory. His assumption that each group forms the memory of its own past, which substantiates its unique identity, continues to be the starting point for all research in this area", says a scholar Barbara Misztal[quoted after: 2].At the same time, M. Halbwach introduced the notion of "collective memory" into memory studies. While another respected scholar in this field, Jan Assmann, following the German academic tradition, appeals to "cultural memory" in his famous works New Frustration with the Culture of Memory and Cultural Memory. Writing, Remembrance, and Political Identity in High Ancient Cultures [3]. At the turn of Millennium the studies of cultural-collective memory experienced significant methodological shifts on the way from a classic to a nonclassic paradigm. Returning to the past becomes more and more problematic which was noticed by Paul Ricoeur in his work Memory, History, Forgetting. He said that the modern culture still cannot identify its approach regarding the past: whether to follow the principle of "sacred memory" or "rational" forgetting ...

\section{FUNCTIONING OF SOCIAL MYTHOLOGY IN THE INDUSTRY OF MEMORY}

Cultural-historical space includes a wide variety of objects in accordance with the Convention Concerning the Protection of World Cultural and Natural Heritage, contributing to the preservation of historical memory. Thus, as of 2017,832 out of the 1073 World Heritage sites, which is the vast majority, are cultural sites [World Heritage // https://en.wikipedia.org/wiki/World_Heritage_site]. 
These are historical pieces of architecture, sculptures and paintings, as well as cultural and historical landmarks (memorial estates, cultural-landscape sites, etc.). However, even with a large number of these sites being protected, this space will not be really filled if its formal "elements" do not acquire a meaning, do not become artifacts that have symbolic content for history and culture. They become a foothold for collective memory not only for individual nations, but for the entire humankind, determine its durability and emotional coloring. After all, collective memory is not just chronicles and cultural objects, but rather updated images of the past that circulate among the masses, fire the imagination of the living and are able to motivate their current actions and deeds.

Recently, the words "cultural image", "historical brand", etc., which are created on the basis of a certain historical and cultural object concept, are increasingly used in relation to cultural space. However, common marketing or economic ways of their creation in a given space do not always work. More often, spiritual bonds as footholds in this field are built with the help of social myth-making, which over the years of its fantastic longevity has proved its functionality and effectiveness. Today, in the socio-spiritual and political spheres, the significance of mythological forms as soft power is almost obvious to political strategists and workers of the "ideological front."

The ambivalent nature of social mythology functioning in the modern information and cultural space is worth mentioning. Amid today's highly dynamic, controversial nation-state communities that are globalizing and constantly changing their dominant points, social myth-making can both contribute to the destruction of nations and the introduction of anomie, spiritual disorientation into the national society, and help preserve identity and culturalcollective memory, striving for ethnic self-identification and strengthening of nationhood[4], [5]. At the same time, the more rapid these processes are, and the more turbulent the information-cultural environment of these processes is, the more effective the mythological forms of influence through their symbolic activities characteristic of them become. How is this achieved?

\section{MeChanism OF SYMBOLIC ACTIVITY In CULTURAL- HISTORICAL SPACE}

The symbol in the myth-consciousness is, according to a well-known Russian researcher A.F. Losev, both a "symbol of the first degree", which is "a living and actual reality", and a "symbol of the second degree" indicating a different not self-explanatory meaning which "is also a symbol" belonging to another layer of mythological space [6].

In the mythological symbolic images that are characterized by syncreticism, the idea that is relevant for the mass subject, an understandable sensual-illustrative image, deep emotions, and intentionality manifested in readiness for action and deeds are merged together. They are manifested to the mass consumer of spiritual and cultural values in an accessible way, because they cut off all the unnecessary, superficial, unimportant, while presenting the essential in an attractive and sympathetic way. This is their fantastic power to influence the public consciousness and change it in the right direction.

The symbolic language of myth is often a "stolen," secondary language that easily adapts to any situation. Symbols-signs as discursive units went through many uses of various semantic contexts and as a result of layerings gradually lost their solid objective meaning, acquired semantic uncertainty bordering on inexhaustibility. Such a sign-symbolic environment is natural for a myth that can easily move from one intuitive-associative semantics to another. Thus, the myth always exists in anticipation of the unexpected and easily captures any, even contradictory situation, while maintaining internal integrity. After all, the symbol of mass consciousness is always an open image, "it is always like an array of possibilities, semantic perspectives" [7], exposing images of collective memory to a certain mythological processing, which can have, as we noted above, a dual effect and ambiguous historical consequences.

Thus, on the one hand, the historical factual environment and the presence of cultural heritage phenomena give relative stability to a dynamic historical and mythological space and define certain boundaries of the interpretative field, which is culture-saving. On the other hand, amid the current informational and ideological war, the main emphasis is not on the superiority of military forces, but on the possibility of spiritual capital destruction, to undermine cultural and historical hegemony with the help of a mobile myth-making mechanism.

All states and ethnic groups are interested in the first trend. After all, the mythologization of collective memory, its embodiment in symbolic images make national history visible and memorable, familiar and understandable, emotionally experienced and inspiring.

In this regard, the Russian idea of the Immortal Regiment can be considered as just genius as it unites touching family myths of the marchers into a single national myth of invincible heirs to the memory of their immortal ancestors, whose sacrifices in World War II were not in vain. The mythologization of this idea made every Russian citizen an actual participant of those distant events during the war of 1941-1945, the successor of traditions and the bearer of collective memory, and the symbolic ritual procession became a huge emotionally unifying and ideologically elevating suggestive force.

\section{ROLE OF CONTEMPORARY MYTHMAKING IN THE DESTINY OF HUMANKIND}

Collective memory is a core of the cultural code in any nation. For its preservation and integration into the living tissue of the modernity just one selection or chronicle of historical facts is obviously not enough. The tendency to present historical events impartially during history classes at school, which appeared during the period of perestroika in Russia and aimed at de-ideologizing of the course, alienated this subject from students and thereby caused damage to the "memory industry" of Russia. The collective memory 
associated with mass consciousness is never impartial, it is always valuable and emotionally colored. And only under this condition, it is safely developed and successfully performs its culture-preserving function.

N. Berdyaev spoke about the need of "sacred" legends in the social consciousness that are mythological in essence and help establish a strong connection, a deep, "union mysterious by principle" between a man and the "cultural-historical", [8]. The mythological tradition "is integrated into some deepest fundamental principle of being, to which it introduces us and which it renders understandable", it introduces society to "revelations about the deepest essence of world reality; about the fate of the world, about human destiny as the central point of the global fate" [9]

In today's world that is becoming more and more complicated, a significant rearrangement of forces and dominant points which are accompanied by the development of a new spiritual atmosphere is observed. In international relations, a new axiology is being created, leading to a revision of the results of World War II and the significance of the forces involved in it. In this situation, the need for "appropriating the past" is as high as ever. And claims for pluralism and democracy here are fully compatible with the authoritarian imposition of their model of history. Russia was one of the first to feel it as the tragic events of the world war occupy a significant place in the Russian spiritual and historical space. It is not surprising that, during the time of perestroika in Russia, the attack on our spiritual bonds began with the demythologization of the heroic past of the USSR. These processes of ideological mythology became problems of social information security, while the functioning and viability of the state and the solution of the tasks of its further spiritual development depended on the solution of those problems. The heroic deed of the Soviet people during the years of the last world war, which occupies an important place in the world historical and value-based informational sphere, was specially attacked. After all, the victory of the USSR over fascist Germany radically influenced the alignment of political forces in the post-war world. And what Fascism failed to do during the war - to defeat the Soviet people and start a new redivision of the world - they tried to do it an ideological way, with the soft power of secondary myth-making during the collapse of the USSR. National heroes, their deeds were discredited by snatching and underlining some important, emotionally perceptible detail through shuffling of associative-intuitive semantic series. Even a detail that is the most insignificant or absurd from a rational point of view, but presented emotionally and accented situationally, became a significant "fact". The attacks on events that are significant for Russia began. A recent example is the use of the "mythological weapon" through a change in the interpretative semantic field in relation to the concept of St. George's Ribbon, which has long functioned as a symbol in a variety of meanings depending on the historical and national situation.

We live in a new reality of political technology and social design, including images of the past in scientific knowledge and mass consciousness. New information tools (with enhanced influence of the visual range, multiple repetition and imposition of basic ideas, pseudo-arguments, etc.) present a new potential for the myth-making of the $21 \mathrm{st}$ century. Such mechanisms of "top-down mythology" development are a novelty of the managed democracy era. It is for a reason that a change in the political course of a country often begins with rewriting and redoing one's own history, the creation of sometimes incredible myths of one's own history, which seem fantastic only to an outside observer. Not the historical facts that need to be proved, but rather their symbolic embodiment - monuments, museums, works of art, rituals, names of streets, etc., which in a concentrated form express axiological and emotional attitudes toward the past, become targeted.

Such methods of demythologization can be used to introduce at first historical forgetfulness - mankurtism (from legend in Chingiz Aitmatov's novel Buranny Polustanok (The Day Lasts More Than a Hundred Years) into the public consciousness of the emerging nation and new state - to forget one's own roots and draw a demarcation line with the former cultural system to clear a place for new myth-making - sacralization of the nation's past as a kind of new value model. Collective memory undergoes a new formatting of public consciousness, deformation - recoding. In the past century, the communist thinker A. Gramsci warned about the significance of such processes for the implementation of the bloodless revolution in any country [10].

Today we are witnessing the world informational redivision of the world, implemented through social mythmaking, which is designed to introduce new values in relation to fundamental world events and entire countries, to carry out a new alignment of forces and change cultural and historical priorities and political dominants. After all, collective memory is biased and largely depends on what is included into it and what is excluded from it.

\section{CONCLUSION}

Thus, in the human history a myth has played and is playing an ambiguous role - both progressive and negative. In the modern dynamic world, this ancient phenomenon continues facing the challenges of time successfully while surprising us with its efficient adaptation to any controversial situation and effective approaches especially in managing cultural values. The academician D.S.Likhachev stated that "memory and knowledge of the past enrich the world, make it interesting, significant, spiritual... Not only do we need to know the history of everything that surrounds us, but also preserve this history, this immense depth of the surroundings" [11].There is no doubt that mythology with its incredible ability to put in order a chaotic and "bustling" worldview through the creation of spiritual bonds in the form of historical-cultural myths can play an important role in these processes.

\section{REFERENCES}

[1] S. Huntington, The Clash of Civilizations. Moscow: AST, 2007, pp $15,22-23$. 
[2] Fundamental Problems of Cultural Studies: collection of articles following the congress /edited by D.L.Spivak. Moscow: Novy Khronograph: Eydos. Vol.6: Cultural Heritage: From Past to Future. 2009, pp.56-69; 59.

[3] A. Assmann, New Frustration with the Culture of Memory/ translated from German by Boris Khlebnikov. Moscow: Novoye literaturnoye obozreniye, 2016, $224 \mathrm{p}$.

[4] O.V. Chistyakova, Self and Other in the communicative space of the global world // Proceedings of the 2017 2rd International Conference on Contemporary Education, Social Sciences and Humanities 2017, pp. 6-11.

[5] O.V. Chistyakova,A view on contemporaneity through the discourse of postmodernism// Proceedings of the 2017 2rd International Conference on Contemporary Education, Social Sciences and Humanities 2017, pp. 96-100.

[6] A.F. Losev, "Phylosophy. Mythology. Culture". Moscow,1991, p.52.

[7] N.N. Rubtsov, Symbol in Art and Life: Philosophical Reflections. Moscow: Nauka, 1991, p.43.

[8] N. Berdyaev, On the Essence of the Historical. Paris: Ymca-press, 1969, http://predanie.ru/berdyaev-nikolayaleksandrovich/book/74421-smysl-istorii/\#/toc2 [accessed date: 5.10.2018]

[9] N.A. Berdyaev, On the Essence of the Historical. Paris: Ymca-press, 1969, http://predanie.ru/berdyaev-nikolayaleksandrovich/book/74421-smysl-istorii/\#/toc2 [accessed date: 5.10.2018].

[10] A. Gramsci, Prison notebooks. Part one. Moscow: Publishing house of political literature, 1991.

[11] D.S. Likhachev, Letters about the Kind and the Beautiful. Moscow: Detskaya literatura, 1988, 238 p., p. 109. 